〔目農医誌 29巻 1 号 22-35頁 昭55.5〕

農村におけるリウマチ性疾患の地域別統計調査成績

広瀬 俊 一, " 野田喜代一"*

\section{はじめに}

慢性関節リウマチをはじめとするいわゆるリウマチ 性疾患の罹患率は，全国的には， $3 \%$ 前後といわれて いる。わが国に批けるこれりウマチ性疾患の発生頻 度については, すでに, 厚生省難病疾患調査が存在する が，農村地域における調査は今まで行われていない。 そこで，わたしどもは農村地域におけるリウマチ性疾 患の実態を把握するために, 全国農協厚生連関連診療 機関にアンケート調査を依頼し，それぞれの機関がと りあつかった診療件数から，その診療圏におけるリウ マチ性疾患の発生頻度を推測してみることにした。

調査疾患はリウマチ性疾患のうち, 慢性関節リウマ チ, 全身性エリテマトーデス, 皮膚筋炎, 多発性笳炎, 強皮症，結節性動脈周囲炎，リウマチ熱に限定した。 診断は現実の診断の状況を知るために各診療機関の自 主性に依存した。今後, 診断基準に照らしての調査が 必要となるものと考えられるが，今回の調査でも，少 なくともこれら診療圈での概況は知り得るものと思わ れる。

\section{調 査 対}

全国厚生連関連医療機関におけるリウマチ性疾患に 関する調査は，九州を除く全国各地区でアンケート形 式により行われた。

各地区別診療機関への依頼数, 回答数および回答率 は, 表 1 , 図 1 のごとくで, 全体としては 48\%の回答 率であった。

回答を頂いた各機関の全診療件数を，年次別，地区 別に集計し，依頼した各地区全体の全診療件数に対す

* 東京大学医学部物療内科

**神奈川歯科大学内科

受付：昭和 54 年 12 月 14 日

本研究は, 昭和 53 年度全共連委託研究として実施した。
表 1.アンケート回答率

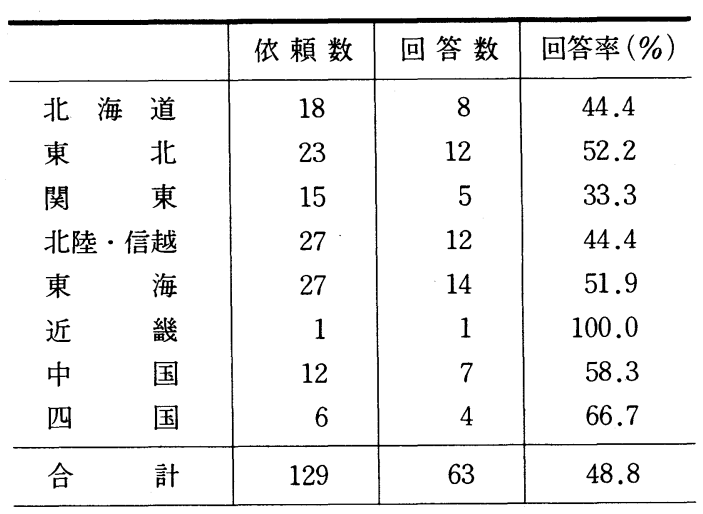

図 1.

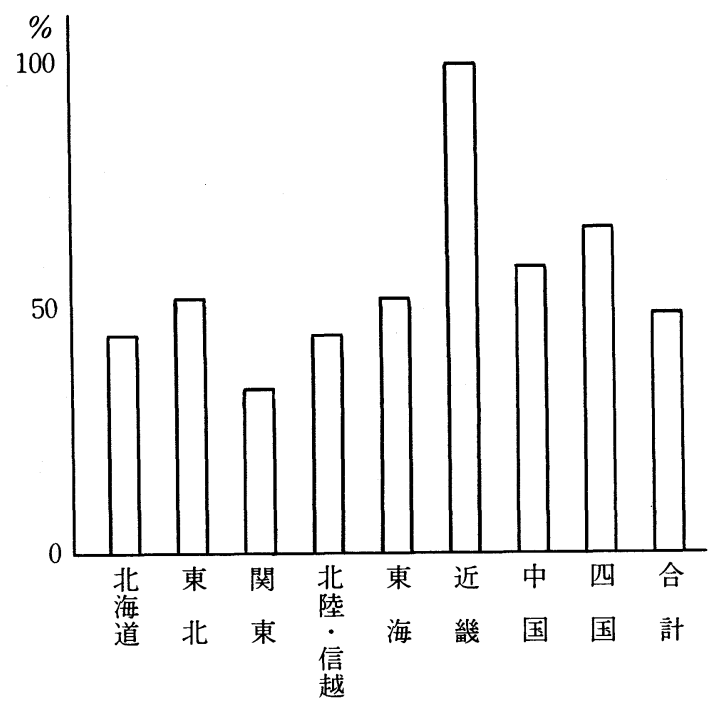

る比率を算出してみると, 表 2 , 図 2 のごとくであっ た。すなわち, 昭和 49 年より 52 年まで各々 $52.0,53.6$, $51.5,51.9 \%$, 全体として $52.2 \%$ となり, 診療件数と 
しても $50 \%$ 超える件数が調査対象となっているこ とを示している。ほとんどの地区で，年度による変動 はみられなかった。したがって, 今回の調査は, 全国
厚生連関連医療機関受診件数の $50 \%$ 超えるものに 対して行われたことになる。

表 2.アンケート回答の診療件数

\begin{tabular}{|c|c|c|c|c|c|c|c|c|c|c|c|}
\hline & & 昭 和 49 & 年 & 昭 和 50 & 年 & 昭 和 51 & 年 & 昭 和 52 & 年 & 合 & 計 \\
\hline 北 海 道 & $\begin{array}{l}\text { (1) 依頼数 } \\
\text { (2)回答数 }\end{array}$ & $\begin{array}{r}2,093,180 \\
710,561\end{array}$ & $\begin{array}{r}\% \\
33.9\end{array}$ & $\begin{array}{r}2,078,708 \\
710,419\end{array}$ & $\begin{array}{r}\% \\
34.2\end{array}$ & $\begin{array}{r}2,049,282 \\
649,403\end{array}$ & $\begin{array}{r}\% \\
31.7\end{array}$ & $\begin{array}{r}2,052,452 \\
660,557\end{array}$ & $\begin{array}{r}\% \\
32.2\end{array}$ & $\begin{array}{l}8,273,622 \\
2,730,940\end{array}$ & $\begin{array}{r}\% \\
33.0\end{array}$ \\
\hline 北 & $\begin{array}{l}\text { 依頼数 } \\
\text { 回答数 }\end{array}$ & $\begin{array}{l}3,250,760 \\
2,151,458\end{array}$ & 66.2 & $\begin{array}{l}3,297,437 \\
2,167,686\end{array}$ & 65.7 & $\begin{array}{l}3,311,613 \\
2,167,165\end{array}$ & 65.4 & $\begin{array}{l}3,331,338 \\
2,181,156\end{array}$ & 65.5 & $\begin{array}{r}13,191,148 \\
8,667,465\end{array}$ & 65.7 \\
\hline 東 & $\begin{array}{l}\text { 依頼数 } \\
\text { 回答数 }\end{array}$ & $\begin{array}{l}2,319,519 \\
1,121,292\end{array}$ & 48.3 & $\begin{array}{l}2,169,736 \\
1,113,138\end{array}$ & 51.3 & $\begin{array}{l}2,456,366 \\
1,153,948\end{array}$ & 47.0 & $\begin{array}{l}2,477,732 \\
1,150,286\end{array}$ & 46.4 & $\begin{array}{l}9,423,353 \\
4,538,664\end{array}$ & 48.2 \\
\hline 北陸·信越 & $\begin{array}{l}\text { 依頼数 } \\
\text { 回答数 }\end{array}$ & $\begin{array}{l}4,814,023 \\
2,264,831\end{array}$ & 47.0 & $\begin{array}{l}4,908,978 \\
2,314,312\end{array}$ & 47.1 & $\begin{array}{l}5,107,498 \\
2,444,530\end{array}$ & 47.9 & $\begin{array}{l}5,165,978 \\
2,527,699\end{array}$ & 48.9 & $\begin{array}{r}19,996,477 \\
9,551,371\end{array}$ & 47.8 \\
\hline 海 & $\begin{array}{l}\text { 依頼数 } \\
\text { 回答数 }\end{array}$ & $\begin{array}{l}5,606,675 \\
2,563,269\end{array}$ & 45.7 & $\begin{array}{l}5,598,442 \\
2,548,266\end{array}$ & 45.5 & $\begin{array}{l}5,562,527 \\
2,460,732\end{array}$ & 44.2 & $\begin{array}{l}5,636,321 \\
2,541,534\end{array}$ & 45.1 & $\begin{array}{l}22,403,965 \\
10,113,802\end{array}$ & 45.1 \\
\hline 畿 & $\begin{array}{l}\text { 佂頼数 } \\
\text { 回答数 }\end{array}$ & $\begin{array}{l}68,875 \\
68,875\end{array}$ & 100 & $\begin{array}{l}64,770 \\
64,770\end{array}$ & 100 & $\begin{array}{l}58,376 \\
58,376\end{array}$ & 100 & $\begin{array}{l}49,247 \\
49,247\end{array}$ & 100 & $\begin{array}{l}241,268 \\
241,268\end{array}$ & 100 \\
\hline 国 & $\begin{array}{l}\text { 䇚頼数 } \\
\text { 回答数 }\end{array}$ & $\begin{array}{r}1,271,033 \\
995,165\end{array}$ & 78.3 & $\begin{array}{l}1,293,525 \\
1,040,400\end{array}$ & 80.4 & $\begin{array}{l}1,248,391 \\
1,011,850\end{array}$ & 81.0 & $\begin{array}{l}1,256,016 \\
1,012,260\end{array}$ & 80.6 & $\begin{array}{l}5,068,965 \\
4,059,675\end{array}$ & 80.0 \\
\hline 国 & $\begin{array}{l}\text { 依頼数 } \\
\text { 回答数 }\end{array}$ & $\begin{array}{r}1,161,605 \\
826,379\end{array}$ & 71.1 & $\begin{array}{l}1,711,808 \\
1,354,574\end{array}$ & 79.1 & $\begin{array}{r}1,302,288 \\
911,816\end{array}$ & 70.0 & $\begin{array}{r}1,303,764 \\
923,533\end{array}$ & 70.8 & $\begin{array}{l}5,479,465 \\
4,016,302\end{array}$ & 73.3 \\
\hline 合 計 & $\begin{array}{l}\text { 依頼数 } \\
\text { 回答数 }\end{array}$ & $\begin{array}{l}20,585,670 \\
10,701,830\end{array}$ & 52.0 & $\begin{array}{l}21,123,404 \\
11,313,565\end{array}$ & 53.6 & $\begin{array}{l}21,096,341 \\
10,857,820\end{array}$ & 51.5 & $\begin{array}{l}21,272,848 \\
11,046,272\end{array}$ & 51.9 & $\begin{array}{l}84,078,263 \\
43,919,487\end{array}$ & 52.2 \\
\hline
\end{tabular}

${ }^{(1)}$ アンケート依頼機関の全診療件数 ${ }^{(2)}$ 回答機関の全診療件数

図 2.アンケート回答のあった診療件数の，アンケート依頼全数に対する百分率

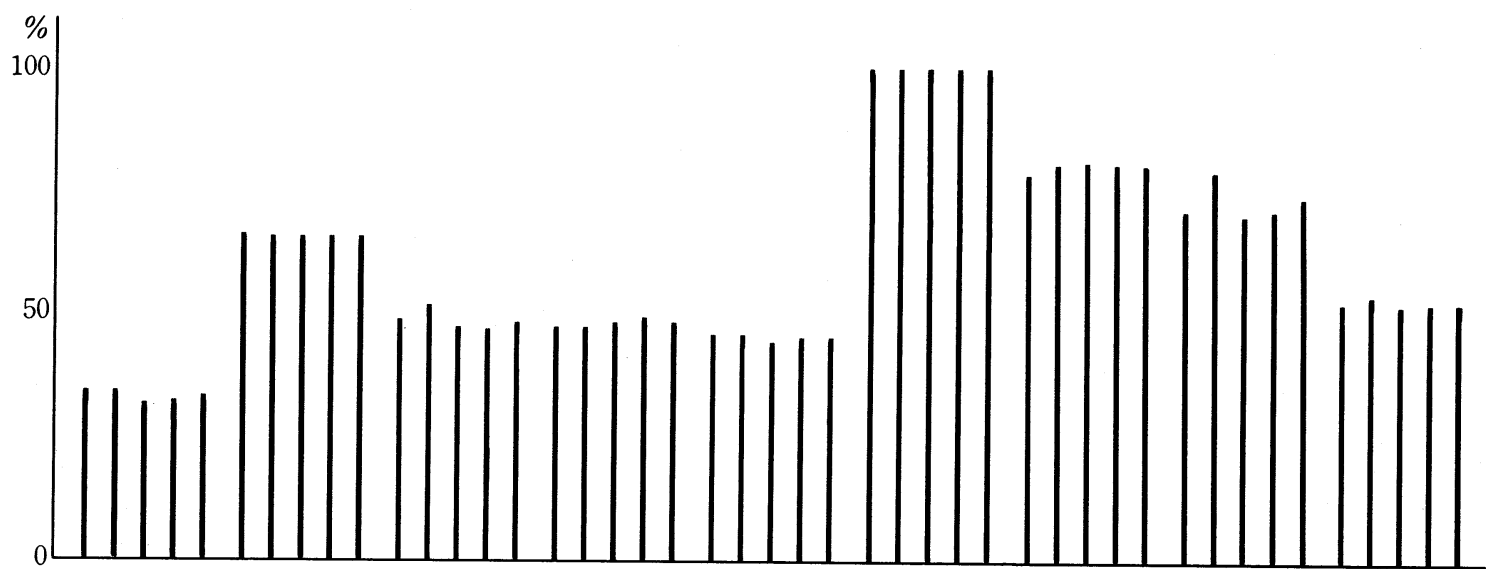

49505152 平 49505152 平 49505152 平 49505152 平 49505152 平 49505152 平 49505152 平 49505152 平 49505152 平 年年年年均 年年年年均 年年年年均年年年年均年年年年均年年年年均年年年年均年年年年均年年年年均

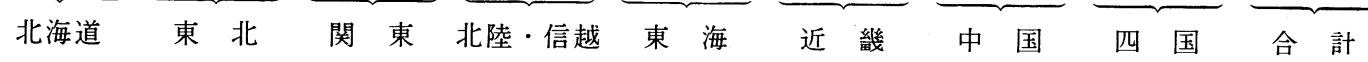




\section{各疾患別の診療件数および頻度}

A．慢性関節リウマチ（RA）（表 3，4）

各地区いずれも年を追って RA 診療件数の増加が 認められる。この傾向は, 診療件数の増加によるのみ でなく，全診療件数に対する比率でも上昇する傾向に ある。

B. 全身性エリテマトーデス（SLE）（表 5，6）

SLE 診療件数は, 全体として増加の傾向は認められ るが，東海，中国，北海道以外は明らかでない。しかし， その全診療件数に対する比率では, 中国, 北海道で上 昇が認められる。

C. 皮膚筋炎 (DM) (表 7, 8)

$\mathrm{DM}$ 診療件数の増加と共に, 地区別では東北で全診 療件数に対する比率の上昇がみられる。

D. 多発性筋炎 $(P M)$ (表 9，10）

全体としての PM 診療件数の増加はあるが, 地区別 での傾向は, PM 診療件数の増加, 全診療件数に対す る比率の上昇もみられない。

E．強皮症（PSS）（表 11，12）

全体としての増加があり，全診療件数に対する比率 の上昇もあるが, 東北, 北陸信越, 東海, 中国に PSS 診療件数の増加がみられる。全診療数に対する比率の 上昇もこれらの地区に認められる。

F. 結節性動脈周囲炎 (PN)（表 13，14）

全体として PN 診療件数の増加がある。中国に地区 的傾向が認められる。全診療件数に対する比率も同じ 傾向をもっている。

G. リウマチ熱（RF）（表 15，16）

全体として RF 診療件数増加は明らかでなく，また， 全診療数に対する比率の増加も明らかでない。地区別 には東北で増加傾向がみられ，また，全診療件数に対 する比率の上昇もみられる。北陸信越では，むしろ， 減少傾向にある。

H. その他の疾患 (ベーチェット病 Beh, シェーグレ ン症候群 $\mathrm{SjS}$, フェルティ一症候群 F, MCTD, 若 年性関節リウマチ JRA, Overlap Syndrome OS) (表 17，18）

これらについては散在し，49-52 年を通じ，Beh が 139 件あり, 以下 $31 ， 3 ， 1 ， 2 ， 2$ 例と僅かであっ た。この全体としての全診療件数に対する比率も 10 万 件当り 4.88 となっている。これらの疾患では, 増加傾 向など不明である。

各疾患の件数，頻度については，何れも増加傾向に
あると思われる。これは, 全診療件数の増加によるの ではなく, 地区による差はあるにしても全診療件数に 対する比率としても増加している。

このことは, 実数が増加していることと共に, 診断 が容易になりつつあり, また, 診療側の認識の問題も あると思われる。

\section{各疾患の各地区での診療件数の全診療件数と の比率 (表 19-26)}

4 年間を通じて, 全診療件数に対する比率からみる と次のごとくになる。

RA は, 関東, 東海, 中国と高く, 逆に北海道, 北陸 信越と低い。

SLE は, 中国, 東北に高く, 四国に低い。

$\mathrm{DM}$ は, 中国, 東北, 北海道に高く, 関東, 四国に 低い。

PM は, 東海, 中国に高く, 北海道, 四国で報告が ない。

PSS は, 東北, 中国に高く, 北海道, 四国に報告が ない。

PN は, 東海に高く, 北海道, 関東, 四国に報告がな い。

$\mathrm{RF}$ は, 関東に高く, 東海, 北海道では低い。

その他 (Beh, SjS, F, MCTD, JRA, OS) では, 一応, 東北, 中国で高く, 東海で低い。

各地区について各疾患をみると, 表 19-26 のごとく で, 何れの地区でも, RA, SLE が多く, RA はすべて でその大部分を占めている。とくに，他疾患との比率 では, 四国, 関東, 東海が多い。

\section{総括および結論}

以上のデーターを全国に打ける各りウマチ性疾患の 患者数,および診療件数と比較することは困難である。 すなわち, 診療圏全体の対象人口が不明であり，また，乙 れらの診断についての問題もある。乙れらについては, より詳細な, すなわち診断基準にのっとってのアン ケート調査が必要である。しかし今回の調査によって, 少なくとも全厚連の診療機関におけるリウマチ性疾患 の動向については知ることができた。そして，そのい ずれの疾患も増加傾向にあることを知った。このさい, とくにこれらの疾患が難病であり，しかも，長期間の 診療を必要とすることを考えると，その対策の樹立は きわめて重要かつ急を要する問題であると考兄られる のである。 
表 3. 慢性関節リウマチ（RA）

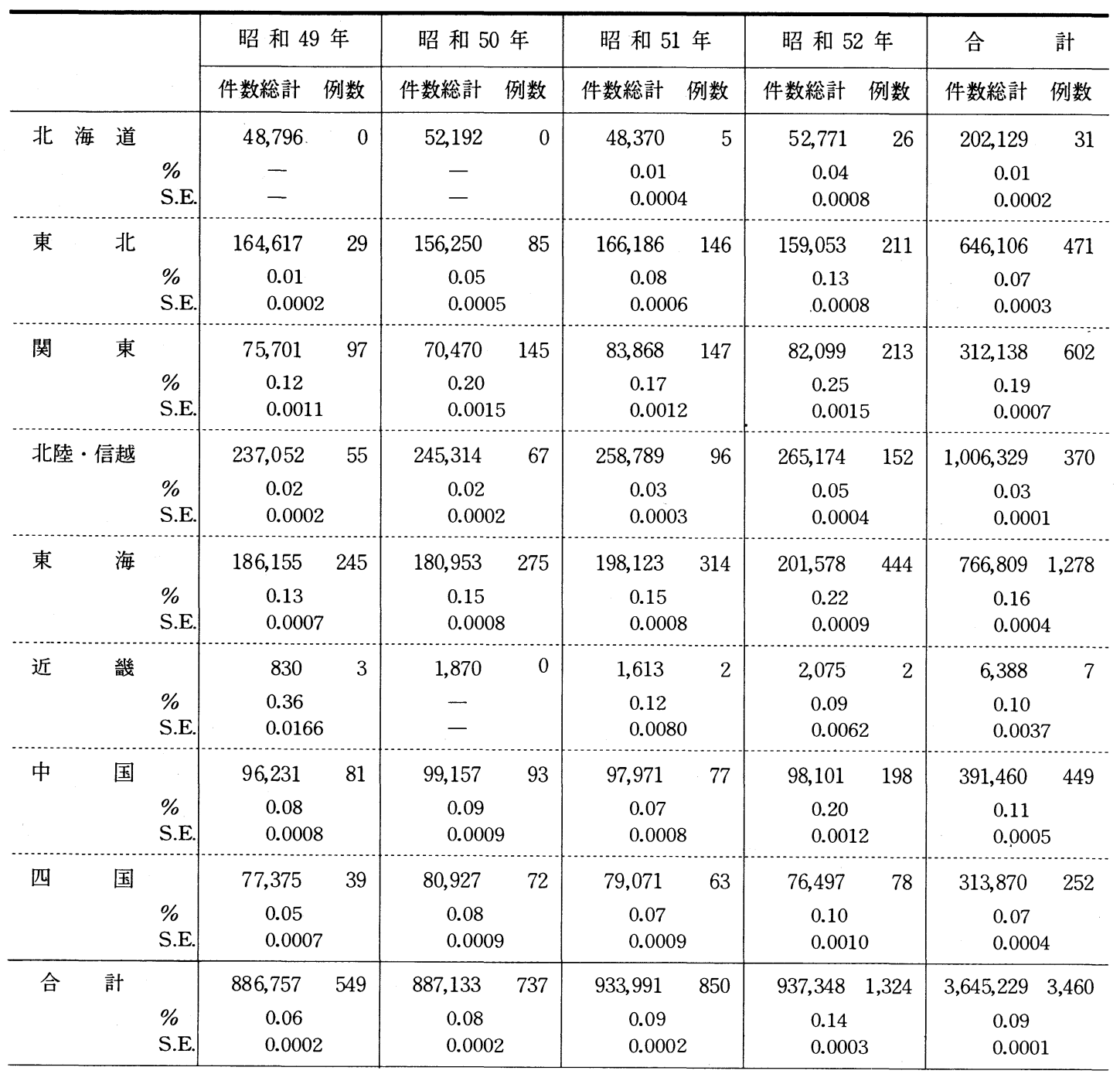

表 4、慢性関節リウマチ $(\mathrm{RA})$ ，患者件数 10 万当り

\begin{tabular}{|c|c|c|c|c|c|}
\hline & 昭和 49 年 & 昭和 50 年 & 昭和 51 年 & 昭和 52 年 & 合計平均 \\
\hline 北 海 道 & 0 & 0 & 10.34 & 49.27 & 15.34 \\
\hline 東 & 17.62 & 54.40 & 87.85 & 132.66 & 72.90 \\
\hline 関 & 128.14 & 205.76 & 175.28 & 259.44 & 192.86 \\
\hline 北陸 - 信越 & 23.20 & 27.31 & 37.10 & 57.32 & 36.77 \\
\hline 東 & 131.61 & 151.97 & 158.49 & 220.26 & 166.66 \\
\hline 近 & 361.45 & 0 & 123.99 & 96.39 & 109.58 \\
\hline 中 & 84.17 & 93.79 & 78.59 & 201.83 & 114.70 \\
\hline 四 & 50.40 & 88.97 & 79.68 & 101.96 & 80.29 \\
\hline 合 & 61.70 & 83.08 & 91.00 & 141.25 & 94.92 \\
\hline
\end{tabular}


(26)

表 5. 全身性エリテマトーデス (SLE)

\begin{tabular}{|c|c|c|c|c|c|c|c|c|c|c|c|c|}
\hline & & & \multicolumn{2}{|c|}{ 昭 和 49 年 } & \multicolumn{2}{|c|}{ 昭 和 50 年 } & \multicolumn{2}{|c|}{ 昭 和 51 年 } & \multicolumn{2}{|c|}{ 昭 和 52 年 } & 合 & \multirow{2}{*}{$\frac{\text { 計 }}{\text { 例数 }}$} \\
\hline & & & 件数総計 倠 & 例数 & 件数総計 例 & 例数 & 件数総計 & 例数 & 件数総計 & 例数 & 件数総計 & \\
\hline 北 海 & 道 & $\begin{array}{l}\% \\
\text { S.E. }\end{array}$ & $\begin{array}{c}48,796 \\
0.00 \\
-\end{array}$ & 1 & $\begin{array}{c}52,192 \\
0.00 \\
-\end{array}$ & 1 & $\begin{array}{c}48,370 \\
0.00 \\
-\end{array}$ & 4 & $\begin{array}{r}52,771 \\
0.00 \\
-\end{array}$ & 5 & $\begin{array}{c}202,129 \\
0.00 \\
-\end{array}$ & 11 \\
\hline 東 & 北 & $\begin{array}{l}\% \\
\text { S.E }\end{array}$ & $\begin{array}{c}164,617 \\
0.01 \\
0.0002\end{array}$ & 20 & $\begin{array}{c}156,250 \\
0.00 \\
-\end{array}$ & 10 & $\begin{array}{c}166,186 \\
0.00 \\
-\end{array}$ & 11 & $\begin{array}{r}159,053 \\
0.00 \\
-\end{array}$ & 14 & $\begin{array}{c}646,106 \\
0.00 \\
-\end{array}$ & 55 \\
\hline 関 & 東 & $\begin{array}{l}\% \\
\text { S.E. }\end{array}$ & $\begin{array}{c}75,701 \\
0.00 \\
-\end{array}$ & 2 & $\begin{array}{l}70,470 \\
0.00 \\
0.0003\end{array}$ & 9 & $\begin{array}{c}83,868 \\
0.00 \\
-\end{array}$ & 5 & $\begin{array}{c}82,099 \\
0.00 \\
-\end{array}$ & 7 & $\begin{array}{c}312,138 \\
0.00 \\
-\end{array}$ & 23 \\
\hline 北陸· & 詰越 & $\begin{array}{l}\% \\
\text { S.E. }\end{array}$ & $\begin{array}{r}237,052 \\
0.00 \\
-\end{array}$ & 11 & $\begin{array}{c}245,314 \\
0.00 \\
-\end{array}$ & 9 & $\begin{array}{r}258,789 \\
0.00 \\
-\quad\end{array}$ & 13 & $\begin{array}{c}265,174 \\
0.00 \\
-\end{array}$ & 16 & $\begin{array}{r}1,006,329 \\
0.00 \\
-\end{array}$ & 49 \\
\hline 東 & 海 & $\begin{array}{l}\% \\
\text { S.E. }\end{array}$ & $\begin{array}{c}186,155 \\
0.00 \\
-\end{array}$ & 7 & $\begin{array}{c}180,953 \\
0.00 \\
-\end{array}$ & 6 & $\begin{array}{r}198,123 \\
0.00 \\
-\end{array}$ & 7 & $\begin{array}{c}201,578 \\
0.00 \\
-\end{array}$ & 13 & $\begin{array}{c}766,809 \\
0.00 \\
- \\
\end{array}$ & 33 \\
\hline 近 & 畿 & $\begin{array}{l}\% \\
\text { S.E. }\end{array}$ & $\begin{array}{l}830 \\
- \\
-\end{array}$ & 0 & $\begin{array}{c}1,870 \\
- \\
-\end{array}$ & 0 & $\begin{array}{c}1,613 \\
- \\
-\end{array}$ & 0 & $\begin{array}{c}2,075 \\
- \\
-\end{array}$ & 0 & $\begin{array}{c}6,388 \\
- \\
-\end{array}$ & 0 \\
\hline 中 & 国 & $\begin{array}{l}\% \\
\text { S.E. }\end{array}$ & $\begin{array}{c}96,231 \\
0.00 \\
-\end{array}$ & 4 & $\begin{array}{c}99,157 \\
0.00 \\
-\end{array}$ & 6 & $\begin{array}{l}97,971 \\
\quad 0.01 \\
0.0003\end{array}$ & 12 & $\begin{array}{c}98,101 \\
0.01 \\
0.0003\end{array}$ & 13 & $\begin{array}{c}391,460 \\
0.00 \\
-\end{array}$ & 35 \\
\hline 四 & 国 & $\begin{array}{l}\% \\
\text { S.E. }\end{array}$ & $\begin{array}{c}77,375 \\
0.00 \\
-\end{array}$ & 2 & $\begin{array}{c}80,927 \\
0.00 \\
-\end{array}$ & 2 & $\begin{array}{c}79,071 \\
0.00 \\
-\end{array}$ & 2 & $\begin{array}{c}76,497 \\
0.00 \\
-\end{array}$ & 1 & $\begin{array}{r}313,870 \\
0.00 \\
-\end{array}$ & 7 \\
\hline 合 & 計 & $\begin{array}{l}\% \\
\text { S.E. }\end{array}$ & $\begin{array}{c}886,757 \\
0.00 \\
-\end{array}$ & 47 & $\begin{array}{r}887,133 \\
0.00 \\
-\end{array}$ & 43 & $\begin{array}{c}933,991 \\
0.00 \\
-\end{array}$ & & $\begin{array}{c}937,348 \\
0.00 \\
-\end{array}$ & 69 & $\begin{array}{r}3,645,229 \\
0.00 \\
-\end{array}$ & 213 \\
\hline
\end{tabular}

表 6. 全身性エリテマトーデス(SLE), 患者件数 10 万当り

\begin{tabular}{|c|c|c|c|c|c|}
\hline & 昭和 49年 & 昭和 50 年 & 昭和 51 年 & 昭和 52 年 & 合計平均 \\
\hline 北 海 道 & 2.05 & 1.92 & 8.27 & 9.47 & 5.44 \\
\hline 北 & 12.15 & 6.40 & 6.62 & 8.80 & 8.51 \\
\hline 関 & 2.64 & 12.77 & 5.96 & 8.53 & 7.37 \\
\hline 北陸·信越 & 4.64 & 3.67 & 5.02 & 6.03 & 4.87 \\
\hline 海 & 3.76 & 3.32 & 3.53 & 6.45 & 4.30 \\
\hline 畿 & 0 & 0 & 0 & 0 & 0 \\
\hline 国 & 4.16 & 6.05 & 12.25 & 13.25 & 8.94 \\
\hline 四 & 2.58 & 2.47 & 2.53 & 1.30 & 2.23 \\
\hline 計 & 5.30 & 4.85 & 5.78 & 7.36 & 5.84 \\
\hline
\end{tabular}


表 7. 皮膚筋炎 (DM)

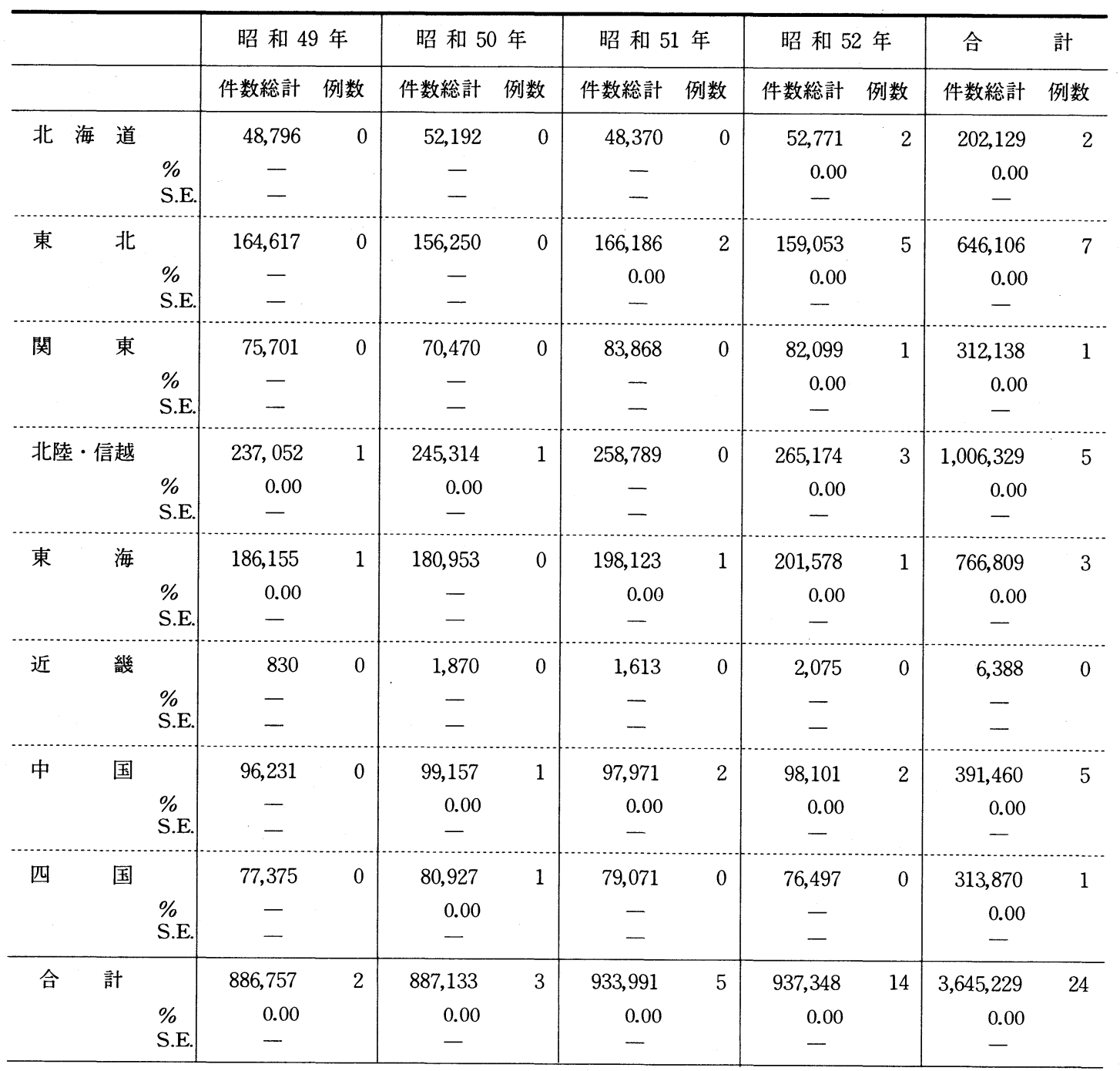

表 8. 皮虐筋炎 $(\mathrm{DM})$, 患者件数 10 万当り

\begin{tabular}{|c|c|c|c|c|c|}
\hline & 昭和49年 & 昭和 50 年 & 昭和 51 年 & 昭和 52 年 & 合計平均 \\
\hline 北 海 道 & 0 & 0 & 0 & 3.79 & 0.99 \\
\hline 北 & 0 & 0 & 1.20 & 3.14 & 1.08 \\
\hline 東 & 0 & 0 & 0 & 1.22 & 0.32 \\
\hline 北陸 - 信越 & 0.42 & 0.41 & 0 & 1.13 & 0.50 \\
\hline 海 & 0.54 & 0 & 0.50 & 0.50 & 0.39 \\
\hline 畿 & 0 & 0 & 0 & 0 & 0 \\
\hline 国 & 0 & 1.01 & 2.04 & 2.04 & 1.28 \\
\hline 国 & 0 & 1.24 & 0 & 0 & 0.32 \\
\hline 合 計 & 0.23 & 0.34 & 0.54 & 1.49 & 0.66 \\
\hline
\end{tabular}


(28)

表 9, 多 発 性 筋 炎 (PM)

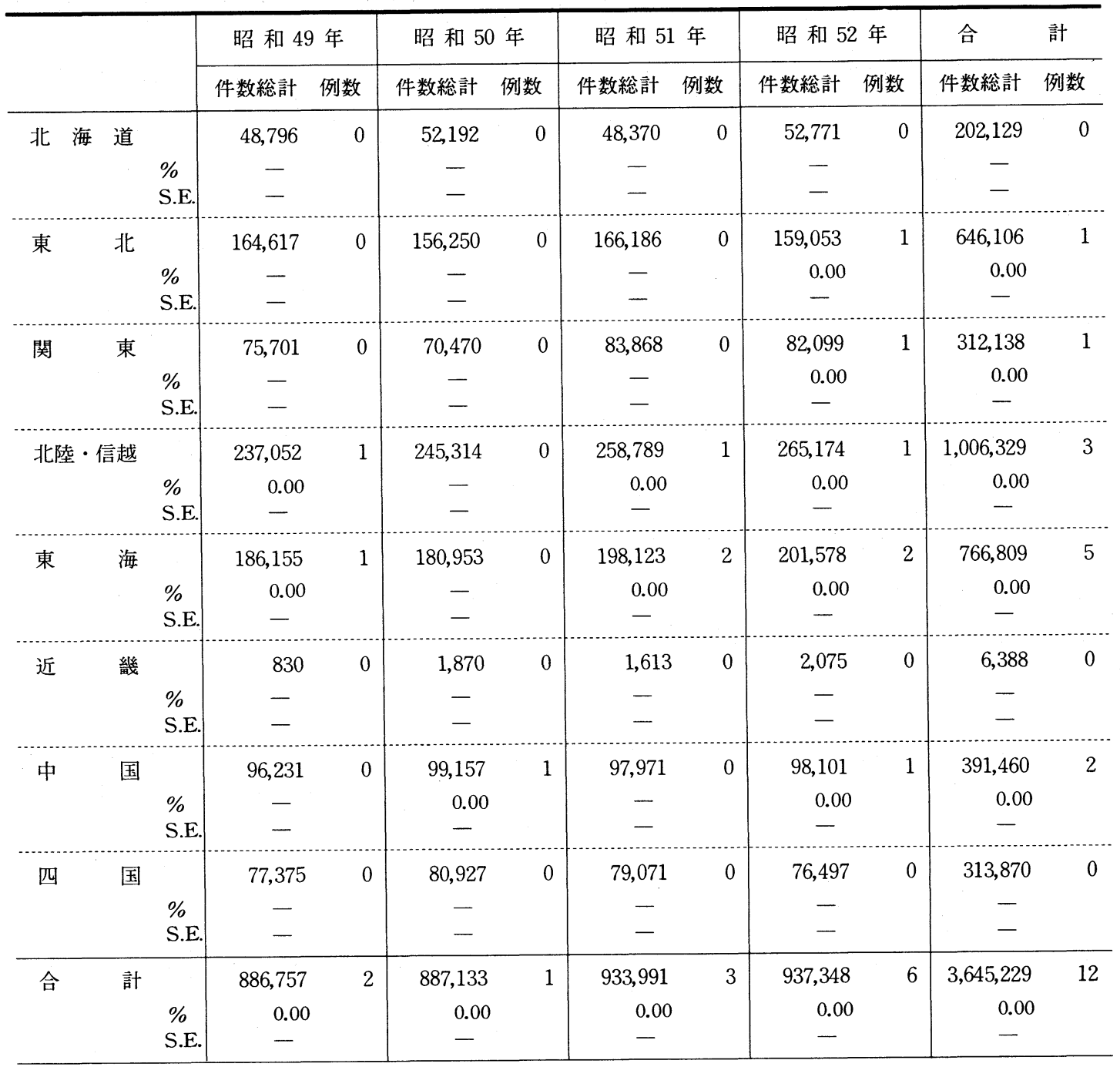

表 10. 多発性筋炎 $(P M)$, 患者件数 10 万当り

\begin{tabular}{|c|c|c|c|c|c|}
\hline & 昭和 49 年 & 昭和 50 年 & 昭和 51 年 & 昭和 52 年 & 合計平均 \\
\hline 北 海 道 & 0 & 0 & 0 & 0 & 0 \\
\hline 東 & 0 & 0 & 0 & 0.63 & 0.15 \\
\hline 関 & 0 & 0 & 0 & 1.22 & 0.32 \\
\hline 北陸 - 信越 & 0.42 & 0 & 0.39 & 0.38 & 0.30 \\
\hline 東 & 0.54 & 0 & 1.01 & 0.99 & 0.65 \\
\hline 近 & 0 & 0 & 0 & 0 & 0 \\
\hline 中 & 0 & 1.01 & 0 & 1.02 & 0.51 \\
\hline 四 & 0 & 0 & 0 & 0 & 0 \\
\hline 合＼cjkstart計 & 0.22 & 0.11 & 0.32 & 0.64 & 0.33 \\
\hline
\end{tabular}


表11. 強皮症（PSS）

\begin{tabular}{|c|c|c|c|c|c|c|c|c|c|c|c|c|}
\hline & & & \multicolumn{2}{|c|}{ 昭 和 49 年 } & \multicolumn{2}{|c|}{ 昭 和 50 年 } & \multicolumn{2}{|c|}{ 昭 和 51 年 } & \multicolumn{2}{|c|}{ 昭 和 52 年 } & \multirow{2}{*}{$\begin{array}{c}\text { 合 } \\
\text { 件数総計 }\end{array}$} & \multirow{2}{*}{$\frac{\text { 計 }}{\text { 例数 }}$} \\
\hline & & & 件数総計 & 例数 & 件数総計 & 例数 & 件数総計 & 例数 & 件数総計 & 例数 & & \\
\hline 北 海 & 道 & $\begin{array}{l}\% \\
\text { S.E. }\end{array}$ & $\begin{array}{c}48,796 \\
- \\
-\end{array}$ & 0 & $\begin{array}{c}52,192 \\
- \\
-\end{array}$ & 0 & $\begin{array}{c}48,370 \\
- \\
-\end{array}$ & 0 & $\begin{array}{c}52,771 \\
- \\
-\end{array}$ & 0 & $\begin{array}{c}202,129 \\
- \\
-\end{array}$ & 0 \\
\hline 東 & 北 & $\begin{array}{l}\% \\
\text { S.E. }\end{array}$ & $\begin{array}{c}164,617 \\
0.00 \\
-\end{array}$ & 2 & $\begin{array}{c}156,250 \\
0.00 \\
-\end{array}$ & 3 & $\begin{array}{c}166,186 \\
0.00 \\
-\end{array}$ & 4 & $\begin{array}{r}159,053 \\
0.00 \\
-\end{array}$ & 7 & $\begin{array}{c}646,106 \\
0.00 \\
-\end{array}$ & 16 \\
\hline 関 & 東 & $\begin{array}{l}\% \\
\text { S.E. }\end{array}$ & $\begin{array}{c}75,701 \\
- \\
-\end{array}$ & 0 & $\begin{array}{c}70,470 \\
- \\
-\end{array}$ & 0 & $\begin{array}{c}83,868 \\
- \\
-\end{array}$ & 0 & $\begin{array}{c}82,099 \\
0.00 \\
-\end{array}$ & 1 & $\begin{array}{c}312,138 \\
0.00 \\
-\end{array}$ & 1 \\
\hline 北陸 . & 信越 & $\begin{array}{l}\% \\
\text { S.E. }\end{array}$ & $\begin{array}{r}237,052 \\
0.00 \\
-\end{array}$ & 3 & $\begin{array}{c}245,314 \\
0.00 \\
-\end{array}$ & 3 & $\begin{array}{c}258,789 \\
0.00 \\
-\end{array}$ & 5 & $\begin{array}{c}265,174 \\
0.00 \\
-\end{array}$ & 6 & $\begin{array}{r}1,006,329 \\
0.00 \\
-\end{array}$ & 17 \\
\hline 東 & 海 & $\begin{array}{l}\% \\
\text { S.E. }\end{array}$ & $\begin{array}{r}186,155 \\
0.00 \\
-\end{array}$ & 1 & $\begin{array}{c}180,953 \\
- \\
-\end{array}$ & 0 & $\begin{array}{c}198,123 \\
- \\
-\end{array}$ & 0 & $\begin{array}{r}201,578 \\
0.00 \\
-\end{array}$ & 5 & $\begin{array}{c}766,809 \\
0.00 \\
- \\
-\end{array}$ & 6 \\
\hline 近 & 畿 & $\begin{array}{l}\% \\
\text { S.E. }\end{array}$ & $\begin{array}{l}830 \\
- \\
-\end{array}$ & 0 & $\begin{array}{c}1,870 \\
- \\
-\end{array}$ & 0 & $\begin{array}{c}1,613 \\
- \\
-\end{array}$ & 0 & $\begin{array}{c}2,075 \\
- \\
-\end{array}$ & 0 & $\begin{array}{c}6,388 \\
- \\
-\end{array}$ & 0 \\
\hline 中 & 国 & $\begin{array}{l}\% \\
\text { S.E. }\end{array}$ & $\begin{array}{r}96,231 \\
0.00 \\
-\end{array}$ & 1 & $\begin{array}{c}99,157 \\
0.00 \\
-\end{array}$ & 1 & $\begin{array}{c}97,971 \\
0.00 \\
-\end{array}$ & 1 & $\begin{array}{r}98,101 \\
0.00 \\
-\end{array}$ & 5 & $\begin{array}{r}391,460 \\
0.00 \\
-\end{array}$ & 8 \\
\hline 四 & 国 & $\begin{array}{l}\% \\
\text { S.E. }\end{array}$ & $\begin{array}{c}77,375 \\
- \\
-\end{array}$ & 0 & $\begin{array}{c}80,927 \\
- \\
-\end{array}$ & 0 & $\begin{array}{c}79,071 \\
- \\
-\end{array}$ & 0 & $\begin{array}{c}76,497 \\
- \\
-\end{array}$ & 0 & $\begin{array}{c}313,870 \\
- \\
-\end{array}$ & 0 \\
\hline 合 & 計 & $\begin{array}{l}\% \\
\text { S.E. }\end{array}$ & $\begin{array}{r}886,757 \\
0.00 \\
-\end{array}$ & 7 & $\begin{array}{r}887,133 \\
0.00 \\
-\end{array}$ & 7 & $\begin{array}{r}933,991 \\
0.00 \\
-\end{array}$ & 10 & $\begin{array}{r}937,348 \\
0.00 \\
-\end{array}$ & 24 & $\begin{array}{r}3,645,229 \\
0.00 \\
-\end{array}$ & 48 \\
\hline
\end{tabular}

表 12. 強皮症 (PSS), 患者件数 10 万当り

\begin{tabular}{|c|c|c|c|c|c|}
\hline & 昭和 49年 & 昭和 50 年 & 昭和 51 年 & 昭和 52年 & 合計平均 \\
\hline 北 海 道 & 0 & 0 & 0 & 0 & 0 \\
\hline 東 北 & 1.21 & 1.92 & 2.41 & 4.40 & 2.48 \\
\hline 関 & 0 & 0 & 0 & 1.22 & 0.32 \\
\hline 北陸·信越 & 1.27 & 1.22 & 1.93 & 2.26 & 1.69 \\
\hline 東 & 0.54 & 0 & 0 & 2.48 & 0.78 \\
\hline 近 & 0 & 0 & 0 & 0 & 0 \\
\hline 中 & 1.04 & 1.01 & 1.02 & 5.10 & 2.04 \\
\hline 国 & 0 & 0 & 0 & 0 & 0 \\
\hline 合 計 & 0.79 & 0.79 & 1.07 & 2.56 & 1.32 \\
\hline
\end{tabular}


(30)

表13. 結節性動 脈 周囲炎 (PN)

\begin{tabular}{|c|c|c|c|c|c|c|c|c|c|c|c|c|}
\hline & & & \multicolumn{2}{|c|}{ 昭 和 49 年 } & \multicolumn{2}{|c|}{ 昭 和 50 年 } & \multicolumn{2}{|c|}{ 昭 和 51 年 } & \multicolumn{2}{|c|}{ 昭 和 52 年 } & 合 & 計 \\
\hline & & & 件数総計 & 例数 & 件数総計 & 例数 & 件数総計 & 例数 & 件数総計 & 例数 & 件数総計 & 例数 \\
\hline 北 汻 & 道 & $\begin{array}{l}\% \\
\text { S.E. }\end{array}$ & $\begin{array}{c}48,796 \\
- \\
-\end{array}$ & 0 & $\begin{array}{c}52,192 \\
- \\
-\end{array}$ & 0 & $\begin{array}{c}48,370 \\
- \\
-\end{array}$ & 0 & $\begin{array}{c}52,771 \\
- \\
-\end{array}$ & 0 & $\begin{array}{c}202,129 \\
- \\
-\end{array}$ & 0 \\
\hline 東 & 北 & $\begin{array}{l}\% \\
\text { S.E. }\end{array}$ & $\begin{array}{c}164,617 \\
- \\
-\end{array}$ & 0 & $\begin{array}{c}156,250 \\
- \\
-\end{array}$ & 0 & $\begin{array}{c}166,186 \\
- \\
-\end{array}$ & 0 & $\begin{array}{r}159,053 \\
0.00 \\
-\end{array}$ & 1 & $\begin{array}{c}646,106 \\
0.00 \\
-\end{array}$ & 1 \\
\hline 関 & 東 & $\begin{array}{l}\% \\
\text { S.E. }\end{array}$ & $\begin{array}{c}75,701 \\
- \\
- \\
\end{array}$ & 0 & $\begin{array}{c}70,470 \\
- \\
- \\
\end{array}$ & 0 & $\begin{array}{c}83,868 \\
- \\
-\end{array}$ & 0 & $\begin{array}{c}82,099 \\
- \\
- \\
\end{array}$ & 0 & $\begin{array}{c}312,138 \\
- \\
-\end{array}$ & 0 \\
\hline 北陸 . & 言越 & $\begin{array}{l}\% \\
\text { S.E. }\end{array}$ & $\begin{array}{c}237,052 \\
- \\
-\end{array}$ & 0 & $\begin{array}{c}245,314 \\
- \\
-\end{array}$ & 0 & $\begin{array}{r}258,789 \\
0.00 \\
-\end{array}$ & 1 & $\begin{array}{c}265,174 \\
- \\
-\end{array}$ & 0 & $\begin{array}{r}1,006,329 \\
0.00 \\
-\end{array}$ & 1 \\
\hline 東 & 海 & $\begin{array}{l} \\
\% \\
\text { S.E. }\end{array}$ & $\begin{array}{r}186,155 \\
0.00 \\
- \\
\end{array}$ & 1 & $\begin{array}{r}180,953 \\
0.00 \\
- \\
\end{array}$ & 1 & $\begin{array}{c}198,123 \\
0.00 \\
-\end{array}$ & 1 & $\begin{array}{c}201,578 \\
0.00 \\
-\end{array}$ & 2 & $\begin{array}{c}766,809 \\
0.00 \\
-\end{array}$ & 5 \\
\hline 近 & 畿 & $\begin{array}{l}\% \\
\text { S.E. }\end{array}$ & $\begin{array}{l}830 \\
- \\
-\end{array}$ & 0 & $\begin{array}{c}1,870 \\
- \\
-\end{array}$ & 0 & $\begin{array}{c}1,613 \\
- \\
-\end{array}$ & 0 & $\begin{array}{c}2,075 \\
- \\
-\end{array}$ & 0 & $\begin{array}{c}6,388 \\
- \\
-\end{array}$ & 0 \\
\hline 中 & 国 & $\begin{array}{l}\% \\
\text { S.E. }\end{array}$ & $\begin{array}{c}96,231 \\
- \\
-\end{array}$ & 0 & $\begin{array}{c}99,157 \\
0.00 \\
-\end{array}$ & 1 & $\begin{array}{c}97,971 \\
0.00 \\
-\end{array}$ & 1 & $\begin{array}{c}98,101 \\
0.00 \\
-\end{array}$ & 3 & $\begin{array}{c}391,460 \\
0.00 \\
-\end{array}$ & 5 \\
\hline 四 & 国 & $\begin{array}{l}\% \\
\text { S.E. }\end{array}$ & $\begin{array}{c}77,375 \\
- \\
-\end{array}$ & 0 & $\begin{array}{c}80,927 \\
- \\
-\end{array}$ & 0 & $\begin{array}{c}79,071 \\
- \\
-\end{array}$ & 0 & $\begin{array}{c}76,497 \\
- \\
-\end{array}$ & 0 & $\begin{array}{c}313,870 \\
- \\
- \\
\end{array}$ & 0 \\
\hline 合 & 計 & $\begin{array}{l}\% \\
\text { S.E. }\end{array}$ & $\begin{array}{c}886,757 \\
0.00 \\
-\end{array}$ & 1 & $\begin{array}{c}887,133 \\
0.00 \\
-\end{array}$ & 2 & $\begin{array}{c}933,991 \\
0.00 \\
-\end{array}$ & 3 & $\begin{array}{c}937,348 \\
0.00 \\
-\end{array}$ & 6 & $\begin{array}{r}3,645,229 \\
0.00 \\
-\end{array}$ & 12 \\
\hline
\end{tabular}

表14. 結節性動脈周囲炎 (PN), 患者件数 10 万当り

\begin{tabular}{|c|c|c|c|c|c|}
\hline & 昭和 49年 & 昭和 50 年 & 昭和 51 年 & 昭和 52 年 & 合計平均 \\
\hline 北 海 道 & 0 & 0 & 0 & 0 & 0 \\
\hline 北 & 0 & 0 & 0 & 0.63 & 0.15 \\
\hline 東 & 0 & 0 & 0 & 0 & 0 \\
\hline 北陸 - 信越 & 0 & 0 & 0.39 & 0 & 0.10 \\
\hline 海 & 0.54 & 0.55 & 0.50 & 0.99 & 0.65 \\
\hline 畿 & 0 & 0 & 0 & 0 & 0 \\
\hline 国 & 0 & 1.01 & 1.02 & 3.06 & 1.28 \\
\hline 国 & 0 & 0 & 0 & 0 & 0 \\
\hline 合計 & 0.11 & 0.23 & 0.32 & 0.64 & 0.33 \\
\hline
\end{tabular}


表15. リウ $マ$ チ 熱 (RF)

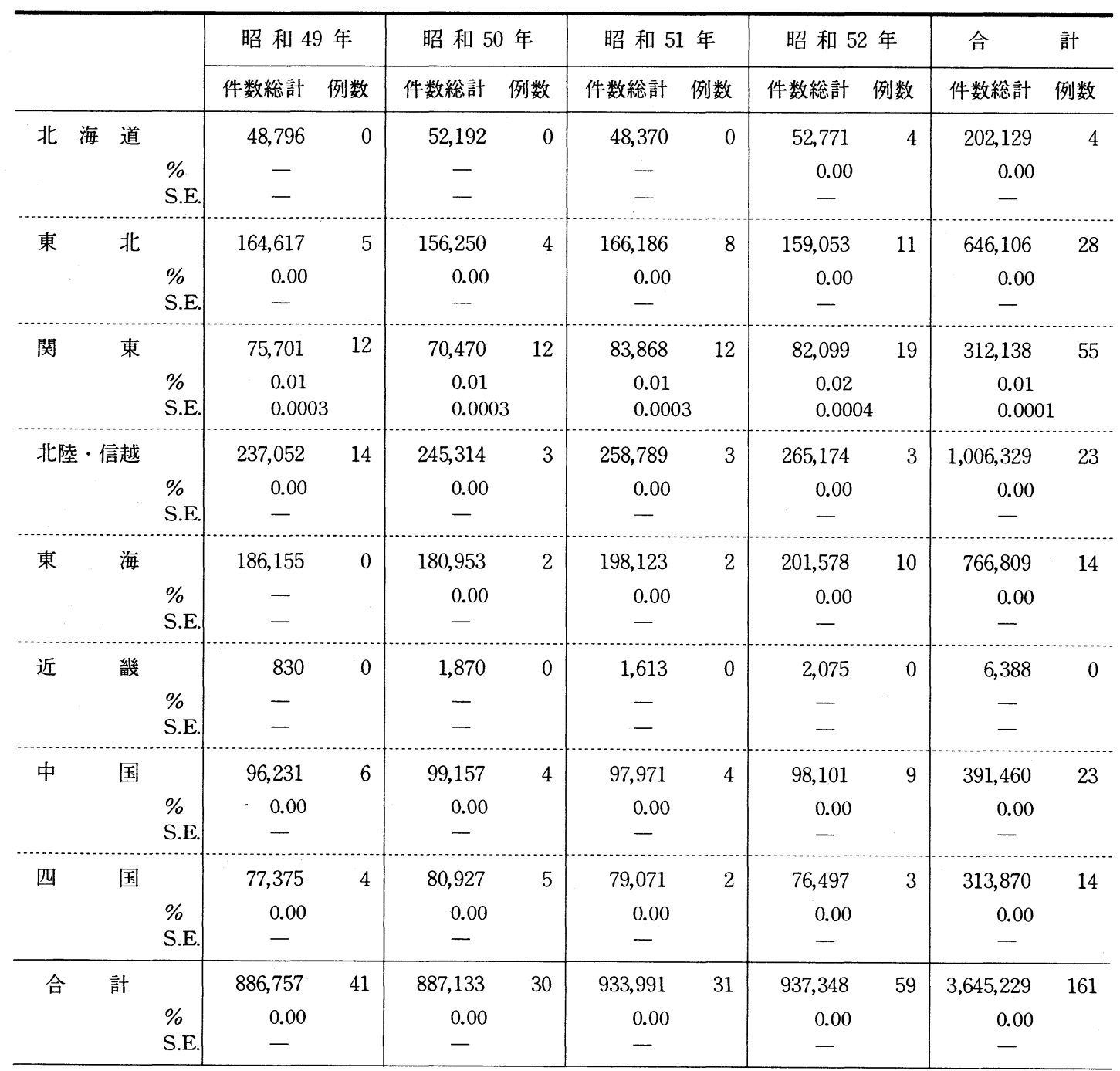

表16. リウマチ熱 $(\mathrm{RF})$, 患者件数 10 万当り

\begin{tabular}{|c|c|c|c|c|c|}
\hline & 昭和 49 年 & 昭和 50 年 & 昭和 51 年 & 昭和 52 年 & 合計平均 \\
\hline 北 海 道 & 0 & 0 & 0 & 7.58 & 1.98 \\
\hline 東 & 3.04 & 2.56 & 4.81 & 6.92 & 4.33 \\
\hline 関 & 15.85 & 17.03 & 14.31 & 23.14 & 17.62 \\
\hline 北陸 - 信越 & 5.91 & 1.22 & 1.16 & 1.13 & 2.29 \\
\hline 海 & 0 & 1.11 & 1.01 & 4.96 & 1.83 \\
\hline 畿 & 0 & 0 & 0 & 0 & 0 \\
\hline 国 & 6.23 & 4.03 & 4.08 & 9.17 & 5.88 \\
\hline 国 & 5.17 & 6.18 & 2.53 & 3.92 & 4.46 \\
\hline 合計 & 4.62 & 3.38 & 3.32 & 6.29 & 4.42 \\
\hline
\end{tabular}


表17. その他のリウマチ性疾患

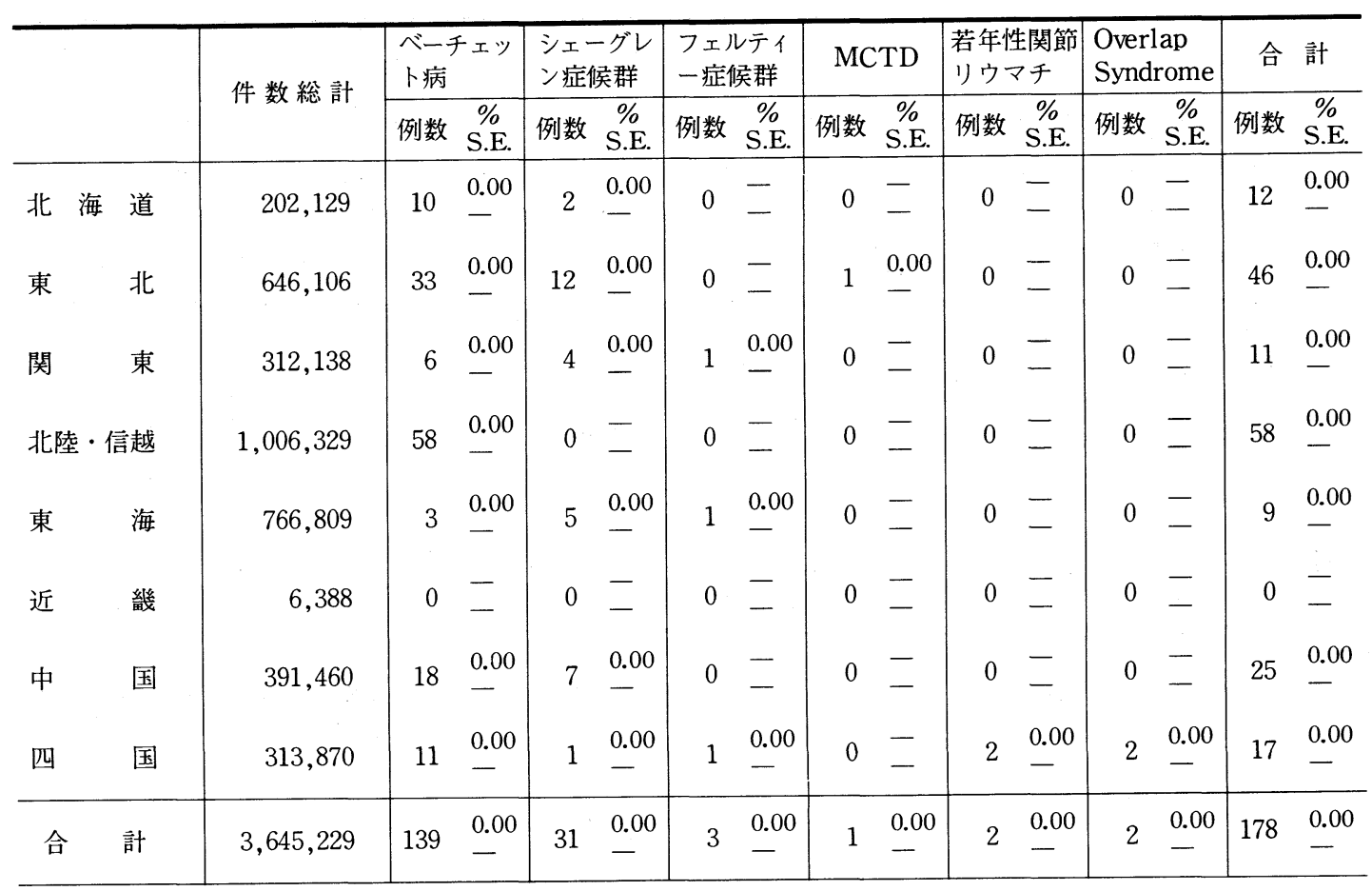

表18. その他のリウマチ性疾患, 患者件数 10 万当り

\begin{tabular}{|c|c|c|c|c|c|c|c|}
\hline & $\begin{array}{l}\text { ベーチェッ } \\
\text { ト病 }\end{array}$ & $\begin{array}{l}\text { シェーグレ } \\
\text { ン症候群 } \\
\end{array}$ & $\begin{array}{l}\text { フェルティ } \\
\text { 一症候群 } \\
\end{array}$ & MCTD & \begin{tabular}{|l|} 
若年性関節 \\
リウマウチ \\
\end{tabular} & \begin{tabular}{|l|} 
Overlap \\
Syndrome \\
\end{tabular} & 合計平均 \\
\hline 北 海 道 & 4.95 & 0.99 & 0 & 0 & 0 & 0 & 5.94 \\
\hline 北 & 5.11 & 1.86 & 0 & 0.15 & 0 & 0 & 7.12 \\
\hline 東 & 1.92 & 1.28 & 0.32 & 0 & 0 & 0 & 3.52 \\
\hline 北陸 · 信越 & 5.76 & 0 & 0 & 0 & 0 & 0 & 5.76 \\
\hline 海 & 0.39 & 0.65 & 0.13 & 0 & 0 & 0 & 1.17 \\
\hline 畿 & 0 & 0 & 0 & 0 & 0 & 0 & 0 \\
\hline 国 & 4.60 & 1.79 & 0 & 0 & 0 & 0 & 6.39 \\
\hline 国 & 3.50 & 0.32 & 0.32 & 0 & 0.64 & 0.64 & 5.42 \\
\hline 合計 & 3.81 & 0.85 & 0.08 & 0.03 & 0.05 & 0.05 & 4.88 \\
\hline
\end{tabular}


(33)

表19. 北 海 道

\begin{tabular}{l|clcc|c}
\hline & 昭.49年 & 昭.50年 & 昭.51 年 & 昭.52 年 & 合計平均 \\
\hline RA & 0 & 0 & 10.34 & 49.27 & 15.34 \\
SLE & 2.05 & 1.92 & 8.27 & 9.47 & 5.44 \\
DM & 0 & 0 & 0 & 3.79 & 0.99 \\
PM & 0 & 0 & 0 & 0 & 0 \\
PSS & 0 & 0 & 0 & 0 & 0 \\
PN & 0 & 0 & 0 & 0 & 0 \\
RF & 0 & 0 & 0 & 7.58 & 1.98 \\
\hline
\end{tabular}

表20. 東 北

(患者件数 10 万当り)

\begin{tabular}{l|ccrr|c}
\hline & 昭.49年 & 昭.50年 & 昭.51年 & 昭.52年 & 合計平均 \\
\hline $\mathrm{RA}$ & 17.62 & 54.40 & 87.85 & 132.66 & 72.90 \\
$\mathrm{SLE}$ & 12.15 & 6.40 & 6.62 & 8.80 & 8.51 \\
$\mathrm{DM}$ & 0 & 0 & 1.20 & 3.14 & 1.08 \\
$\mathrm{PM}$ & 0 & 0 & 0 & 0.63 & 0.15 \\
$\mathrm{PSS}$ & 1.21 & 1.92 & 2.41 & 4.40 & 2.48 \\
$\mathrm{PN}$ & 0 & 0 & 0 & 0.63 & 0.15 \\
$\mathrm{RF}$ & 3.04 & 2.56 & 4.81 & 6.92 & 4.33 \\
\hline
\end{tabular}

表21. 関 東

(患者件数 10 万当り)

\begin{tabular}{l|cccr|r}
\hline & 昭.49年 & 昭.50年 & 昭.51年 & 昭.52年 & 合計平均 \\
\hline RA & 128.14 & 205.76 & 175.28 & 259.44 & 192.86 \\
SLE & 2.64 & 12.77 & 5.96 & 8.53 & 7.37 \\
DM & 0 & 0 & 0 & 1.22 & 0.32 \\
PM & 0 & 0 & 0 & 1.22 & 0.32 \\
PSS & 0 & 0 & 0 & 1.22 & 0.32 \\
PN & 0 & 0 & 0 & 0 & 0 \\
RF & 15.85 & 17.03 & 14.31 & 23.14 & 17.62 \\
\hline
\end{tabular}

表22. 北陸 - 信越

(患者件数 10 万当り)

\begin{tabular}{l|rrrr|c}
\hline & 昭.49年 & 昭.50年 & 昭.51 年 & 昭.52年 & 合計平均 \\
\hline RA & 23.20 & 27.31 & 37.10 & 57.32 & 36.77 \\
SLE & 4.64 & 3.67 & 5.02 & 6.03 & 4.87 \\
DM & 0.42 & 0.41 & 0 & 1.13 & 0.50 \\
PM & 0.42 & 0 & 0.39 & 0.38 & 0.30 \\
PSS & 1.27 & 1.22 & 1.93 & 2.26 & 1.69 \\
PN & 0 & 0 & 0.39 & 0 & 0.10 \\
RF & 5.91 & 1.22 & 1.16 & 1.13 & 2.29 \\
\hline
\end{tabular}

表23. 東 海

\begin{tabular}{l|rrrr|r}
\hline & 昭.49年 & 昭.50年 & 昭.51年 & 昭.52年 & 合計平均 \\
\hline $\mathrm{RA}$ & 131.61 & 151.97 & 158.49 & 220.26 & 166.66 \\
$\mathrm{SLE}$ & 3.76 & 3.32 & 3.53 & 6.45 & 4.30 \\
$\mathrm{DM}$ & 0.54 & 0 & 0.50 & 0.50 & 0.39 \\
$\mathrm{PM}$ & 0.54 & 0 & 1.01 & 0.99 & 0.65 \\
$\mathrm{PSS}$ & 0.54 & 0 & 0 & 2.48 & 0.78 \\
$\mathrm{PN}$ & 0.54 & 0.55 & 0.50 & 0.99 & 0.65 \\
$\mathrm{RF}$ & 0 & 1.11 & 1.01 & 4.96 & 1.83 \\
\hline
\end{tabular}

表24. 近畿

(患者件数 10 万当り)

\begin{tabular}{l|cccc|c}
\hline & 昭.49年 & 昭.50年 & 昭.51年 & 昭.52年 & 合計平均 \\
\hline RA & 361.45 & 0 & 123.99 & 96.39 & 109.58 \\
SLE & 0 & 0 & 0 & 0 & 0 \\
DM & 0 & 0 & 0 & 0 & 0 \\
PM & 0 & 0 & 0 & 0 & 0 \\
PSS & 0 & 0 & 0 & 0 & 0 \\
PN & 0 & 0 & 0 & 0 & 0 \\
RF & 0 & 0 & 0 & 0 & 0 \\
\hline
\end{tabular}

表25.中国

(患者件数 10 万当り)

\begin{tabular}{l|crrr|r}
\hline & 昭.49年 & 昭.50年 & 昭.51年 & 昭.52年 & 合計平均 \\
\hline $\mathrm{RA}$ & 84.17 & 93.79 & 78.59 & 201.83 & 114.70 \\
$\mathrm{SLE}$ & 4.16 & 6.05 & 12.25 & 13.25 & 8.94 \\
$\mathrm{DM}$ & 0 & 1.01 & 2.04 & 2.04 & 1.28 \\
$\mathrm{PM}$ & 0 & 1.01 & 0 & 1.02 & 0.51 \\
$\mathrm{PSS}$ & 1.04 & 1.01 & 1.02 & 5.10 & 2.04 \\
$\mathrm{PN}$ & 0 & 1.01 & 1.02 & 3.06 & 1.28 \\
$\mathrm{RF}$ & 6.23 & 4.03 & 4.08 & 9.17 & 5.88 \\
\hline
\end{tabular}

表26. 国国

(患者件数 10 万当り)

\begin{tabular}{l|cccc|c}
\hline & 昭.49年 & 昭.50年 & 昭.51年 & 昭.52年 & 合計平均 \\
\hline $\mathrm{RA}$ & 50.40 & 88.97 & 79.68 & 101.96 & 80.29 \\
$\mathrm{SLE}$ & 2.58 & 2.47 & 2.53 & 1.30 & 2.23 \\
$\mathrm{DM}$ & 0 & 1.24 & 0 & 0 & 0.32 \\
$\mathrm{PM}$ & 0 & 0 & 0 & 0 & 0 \\
$\mathrm{PSS}$ & 0 & 0 & 0 & 0 & 0 \\
$\mathrm{PN}$ & 0 & 0 & 0 & 0 & 0 \\
$\mathrm{RF}$ & 5.17 & 6.18 & 2.53 & 3.92 & 4.46 \\
\hline
\end{tabular}


(34)

本稿を終るに当って，たいへん多忙な診療の時間を割いて，本 調査に御協力を賜った全国各医療機関の名称を記し, 深甚の感謝 の意を表します。また, 本調査に当って, 貴重な御助言と御援助 を賜った全国共済連医務部長井上喜美雄博士，日本農村医学会事 務局平塚義一事務局長ならびに林弘子女史に厚く感謝いたします。

御協力を賜った諸医療機関および院長名

\section{北海道地区}

総合病院帯広厚生病院（石丸 修） 勤務協中央病院（藤井敬三） 北海道栄養短大（田坂重元） 網走厚生総合病院 (香取力勇) 上湧別厚生病院（松田 禅） 沼田厚生病院（近江谷淳一） 丸瀬布厚生病院（金谷 隆）

\section{東北地区}

[岩手県]

岩手県立山田病院（高野喜正）

$$
\text { [秋田県] }
$$

西成診療所（西成辰雄） 山本組合総合病院 (大㴊宏道) 秋田組合総合病院（峯木照夫） 仙北組合総合病院（五十嵐卓） 平鹿総合病院（林 茂樹） 雄勝中央病院（西村 宏）

[福島県]

白河厚生総合病院（峯山 泰） 塙厚生病院 (岩間倫男) 高田厚生病院（阿部吉夫） 坂下厚生総合病院（村上秀達） 鹿島厚生病院（菊田重治）

\section{関東地区 \\ [茨城県] \\ 総合病院水戸協同病院（鈴木達也） 高萩協同病院 (浦井利雄)}

[栃木県]

上都賀病院（石塚正治） 佐野厚生病院（武井 宏）

\author{
[埼玉県] \\ 幸手総合病院（水間正冬）

\section{北陸, 信越地区} \\ [長野県] \\ 篠ノ井病院（新村 明） \\ 信州大学公衆衛生（釷本 完） \\ 〔新潟県〕
}

糸魚川病院（板谷啓司）

頸南病院（岡田宏一）

上越総合病院（樽田 佐）

中条病院（広瀬辰夫）

魚沼総合病院（小林祥悟）

中央綜合病院 (亀山宏平)

三条総合病院（中川昭英）

佐渡総合病院（瀬川宗助）

羽茂病院 (鉿木芳郎)

[富山県]

高岡病院（林脩）

\section{東海地区 \\ [静岡県〕}

遠州総合病院（安田正憲）

静岡厚生病院（榎本敏雄）

中伊豆温泉病院（間 得之）

[愛知県]

愛北病院（伊藤恭平）

昭和病院 (加藤 始)

尾西病院（木村章二）

$$
\text { [三重県] }
$$

中勢総合病院 (筒井淳平) 員弁厚生病院（水野貴男）
南島病院（江川義勝）

鉿鹿厚生病院（桜井慎一郎）

[岐阜県]

総合病院昭和病院（黒岩秀夫）

揖斐病院（星野睦夫）

岐北病院（樫木良友）

和良村国保病院（中野重男）

\section{近幾地区}

[大阪府]

農協立横山病院（広嶋明男）

\section{中国地区}

[広島県]

尾道総合病院（小先誠也） 広島総合病院（高科成良） 府中総合病院（高田超爾） 広島大学第 2 内科（西本幸男教授）

$$
\text { [山口県] }
$$

周東総合病院（有馬和雄） 長門総合病院（中山 純） 滝部病院（橋本正輝）

\section{四国地区 \\ [徳島県]}

麻植協同病院 (平野穣一)

[香川県]

屋島総合病院（北出公俊） 滝宮病院（塩田欣栄）

[高知県]

農協総合病院（高木義博） 


\title{
Statistical Study of Rheumatic Diseases in Rural Popuration in Different Parts of Japan
}

\author{
Shunichi Hirose* and Kiyoichi Noda
}

Incidence of rheumatic diseases including rheumatoid arthritis falls to about 3 per cent of the whole population in Japan, but there has been no particular survey made so far in regard to rural population. With a view to grasping the situation of rheumatic diseases among rural people, we sent out a questionnaire to each medical service under the Agricultural Cooperative Association, and tried to surmise the incidence of these diseases in the locality on the basis of the number of patients treated by it. Disgnostic criteria of rheumatic diseases rested with each service. For each type of disease the rate of cases treated in each district against the total number of cases was obtained. Throughout the four year period of survey, the following trends were observed with regard to such rates: (1) Incidence of rheumatoid arthritis(RA)was higher in Kanto, Tokai and Chugoku districts, while it was lower in Hokkaido and Hokuriku-Shin-etsu districts ; (2) Incidence of systemic lupus erythematosus (SLE) was higher in Chugoku and Tohoku districts, and was lower in Shikoku district ; (3) Incidence of dermatomyositis (DM) was higer in Chugoku, Tohoku and Hokkaido districts, and lower in Kanto and Shikoku districts ; (4) Incidence of polymyositis (PM) was higher in Tokai and Chugoku districts, while it was not reported from Hokkaido and Shikoku districts ; (5) Incidence of scleroderma (PSS) was higher in Tohoku and Chugoku districts, but it was not reported from Hokkaido and Shikoku districts; (6) Incidence of periarteritis nodosa (PN) was higher in Tokai district, but was not reported from Hokkaido, Kanto and Shikoku districts ; (7) Incidence of rheumatic fever (RF) was higher in Kanto district and lower in Tokai and Hokkaido districts; (8) Incidence of Behcet's syndrome (Beh), Sjogren's syndrome ( $\mathrm{SjS})$, Felty's syndrome (F), mixed connective tissue disease (MCTD), juvenile rheumatoid arthritis (JRA), overlap syndrome (OS) was on the whole higer in Tohoku and Chugoku districts, and lower in Tokai district.

Through this survey, we could at least gain a general view of rheumatic diseases treated in medical services under the Agricultural Cooperative Association. It became also clear that all of these diseases were on the increase. Further survey will have to be made in the near future in the light of respective diagnostic criteria.

* Department of Internal Medicine and Physical Therapy, Faculty of Medicine, Tokyo University

** Department of Internal Medicine, Kanagawa Dental College 